\title{
The Sociological Gaze
}

\begin{abstract}
This chapter provides an explanation and context for situating the particular approach of sociology to the social phenomenon of the uses of forensic genetics in criminal justice systems. The aim is to describe, in an accessible manner, why the governance of crime using science and technology is a fertile domain for sociological enquiry and identify its distinctive features. This chapter provides a comprehensive overview of the main lines of enquiry and concepts of sociological paradigms, namely by focusing on the continuum, tensions and translations between distinctive levels of analysis: micro-macro and objective-subjective. The presentation of the lines of social thought and concepts is accompanied by a brief reference to practical cases of empirical research related to the use of forensic genetics in the criminal justice system. The chapter will enable the reader to acquire theoretical and analytical skills which may be applied in academic research into the various topics and themes addressed in the book's different chapters.
\end{abstract}

Keywords Sociological paradigms $\bullet$ Micro and macro $\bullet$ Objective and subjective $\bullet$ Consensus and conflict 


\section{Paradigms of Sociological Thought}

Sociology is a scientific discipline that presents different theoreticalanalytical lines of thought to question society. Therefore, the sociological gaze upon forensic genetics and its role in the governance of crime is liable to adopt different ways to question our social reality. The main goal of this chapter is to systematize the main guiding lines of sociological theories and indicate how they may be applied to the study and analysis of forensic genetics in criminal justice systems.

According to George Ritzer's point of view (1992), it is possible to distinguish three main paradigms in sociological thought: the paradigms of the social-facts, social-definition and social-behaviour. The last of these paradigms is linked to an analysis model close to experimental psychology, based on social behaviourism models. Considering that such paradigm has no representation in sociological approaches to forensic genetics, it will not be addressed in this work.

The social-facts paradigm focuses on what Émile Durkheim (1895 [1964], 1897 [1951]) termed as social facts: values, cultural norms and social structures that transcend the individual and can exercise social control. Theorists who adhere to this paradigm study social structures and institutions on a large scale. In terms of favoured research methods, they tend to adopt structured interviews and questionnaires, as well as historicalcomparative methods. The social-facts paradigm encompasses a number of theoretical perspectives. Different or even opposing sociological theories can be framed by this paradigm: both structural functionalism (usually associated with the work of Talcott Parsons and his followers) and the so-called conflict theories (who were founded by Karl Marx). According to Ritzer, "Structural-functional theorists tend to see social facts as neatly interrelated and order as maintained by general consensus. Conflict Theorists tend to emphasize disorder among social facts as well as the notion that order is maintained by coercive forces in society" (Ritzer, 1992, p. 641).

Concrete examples are presented for the application of this paradigm when analysing the role of forensic genetics in the governance of crime: a functional perspective will tend to focus on the modes whereby sociotechnical systems can foster cooperation, solidarity and harmony between social groups, as well on the forms whereby controversies can be solved and stabilized. Regarding the social expectations about the role of forensic genetics in the governance of crime, this perspective will be interested in studying the way police cooperation among countries can contribute to make society safer. On the contrary, the standpoint of conflict theories will 
argue that technology should be regarded as the outcome of conflicting ideas and interests, being liable to reflect social relationships marked by domination by one of the parties and mirror social and economic inequalities (Hard, 1993). This perspective will look at international security policies as a mechanism for social control that is able to boost geopolitical inequalities and reflects the interests of the most powerful social groups.

The social-definition paradigm follows an approach based on understanding and interpreting social action, and is inspired by the works of Max Weber (1949). This paradigm is focused on analysing the way that the social actors define their social relationships and their connected social contexts, as well as the effects of those definitions on the development of actions and interactions. In terms of methods, this paradigm privileges unstructured or semi-structured interviews, as well as the direct observation of social interactions. Several sociological theories can be included in this paradigm: action theory, symbolic interactionism, phenomenology, ethnomethodology and existentialism.

Many authors have defended that sociology must integrate the various paradigms and not establish hermetic, rigorous divisions between social structures and human agency. A multi-paradigm perspective will assume that the social world is constituted by multiple social phenomena, which require different levels of analysis but are mutually dependent. However, it is useful taking into consideration various paradigms and conceptual schemes that help identify and understand the complexities of the social world (Table 2.1).

Table 2.1 Paradigms of sociological thought

\begin{tabular}{lll}
\hline & \multicolumn{2}{l}{ Paradigm } \\
\cline { 2 - 3 } & Social facts & Social definition \\
\hline Main authors & Émile Durkheim & Max Weber \\
Basic concepts & Social structure & Human agency \\
Object of the & Values, cultural norms and & Social relationships and interactions \\
study & Social structures & \\
Methods & Structured interviews & Unstructured interviews \\
& Questionnaires & Semi-structured interviews \\
Sociological & Historical-comparative methods & Direct observation of social interaction \\
theories & Structural functionalism & Action theory \\
& Conflict theories & Symbolic interactionism Phenomenology \\
& & Ethnomethodology \\
& & Existentialism
\end{tabular}




\section{Social Studies of Forensic Genetics}

\section{Inauguration of the Field of Study}

Several studies undertaken in the field of social studies for forensic genetics come close to the Social-Definition Paradigm, inasmuch as a considerable part of the research performed is interested in perceptions, expectations and representations that the social actors confer to forensic genetics technologies. A paradigmatic example of this type of research based on understanding and interpreting social situations can be seen in the works of sociologist Michael Lynch, who was fundamental in the inauguration and development of the field of social studies in forensic genetics. This author made use of ethnomethodology, a method of sociological analysis that examines how individuals use everyday conversation to construct a common-sense view of the world (Lynch, 1993).

In this regard, we should highlight the study developed by Michael Lynch and a team of sociologists and other social scientists, with the support of the National Science Foundation and the Department of Science and Technology at Cornell University. The authors developed a multilocation study that involved the UK and the US while covering a period of 15 years. This period ranges from the moment DNA technologies began to be actively discussed in courts and scientific journals (the late 80s) until the time such technologies were established as the "gold standard" (Lynch, Cole, McNally, \& Jordan, 2008, p. xiii). This far-reaching work made use of document analysis, conduction of interviews with scientists and professionals working for the criminal justice system and observation of scientific laboratories and criminal trials.

With the goal of studying the intersection between science and law, the credibility of expert testimony, and historical comparisons between DNA evidence and other criminal identification tools, this team developed work that, although focusing on a "micro" dimension of reality-the perceptions attributed to DNA technology-sought to conjugate it with a "macro" analysis that made it possible to frame and give historic and social meaning to the materials being collected and analysed. The study's results showed very clearly this duality. In order to explain how forensic DNA evidence increasingly gained an exceptional factual status in courts of law, Lynch and his colleagues showed that the objectivity and infallibility attributed to DNA evidence is the result of practical, day-to-day actions, a phenomenon named "administrative objectivity". This administrative 
objectivity of DNA evidence rests upon observable and reportable bureaucratic rules, records, recording devices, protocols and architectural arrangements (Lynch, 2013; Lynch et al., 2008). Beyond those points, the team also showed how the controversies around DNA profiling technologies reflect different professional interests and mirror socio-political and structural aspects linked to the criminal justice system of the US (Daemmrich, 1998; Jasanoff, 1995)

Despite its ethnographic character, this study is a paradigmatic example of the potential of integrating various sociological paradigms. This collective work originated the pivotal publications "Truth machine: The contentious history of DNA fingerprinting" (Lynch et al., 2008). Other results of this study were published in 1998, on a special issue of the journal Social Studies of Science, which continues to be one of the most prestigious publications in the field of social sciences focusing on science and technology. This special issue analysed the presence of forensic genetics in courts, and among other aspects tried to understand the implications of two different ways of acting and thinking coming together: the world of science and the world of law.

One of the study cases undertaken by Michael Lynch's team, addressed in this special issue of the journal Social Studies of Science, was the criminal trial of O.J. Simpson, an American actor and former football player. In 1994, O.J. Simpson was accused of murdering his ex-wife Nicole Brown and her friend Ronald Goldman. DNA evidence was presented during the criminal trial: both the defence and the prosecution called specialists to court who had published about DNA profiling techniques, which led to a heated debate on the controversies brought to the fore by this scientific technique. The case opened a complex field of questioning with several sociological ramifications, namely in terms of issues linked to the interpretation of DNA evidence, public versus expert understanding of science, adequate and inadequate practices, as well as the relationship between the credibility of the DNA evidence and the larger infrastructure that supports the activities of both police forces and scientists (Lynch \& Jasanoff, 1998).

\section{Relationship Between the Macro and Micro Level}

Most classic sociological theories study the new social structures that have emerged during modernity, which made it possible for scientific knowledge to penetrate and transform social relationships. Several of these structures frame scientific development and have allowed its expansion 
and legitimacy, supporting the social, historic and economic process that transformed science into one of the most important modern institutions. For example, classical authors analysed bureaucracy (Max Weber), capitalism (Karl Marx) or organic solidarity (Émile Durkheim). Various authors have debated the existing tension between macro and micro levels, trying to understand the connections between both levels of analysis, while giving birth to a fruitful and extended debate about the tension and ways to articulate human agency and social structure (Bourdieu, 1977; Giddens, 1979, 1984).

Such an analysis about the macro and micro levels is also fundamental to understand how knowledge prerogatives regarding DNA technologies translate, on the one hand, the meaning, intention and interpretation given by one or more social actors and, on the other hand, the broader social structures and contexts. A close analysis of the creation and development of those interactions and social structures is helpful to understand how a single act to vindicate the plausibility of a technology that extracts DNA profiles from biological samples ("discovered" by one individual or particular groups, in a specific point in time and space) has become part of a broader social structure. How did that knowledge-"scientific breakthrough"- stabilize? Which new relationships and social structures were formed and consolidated by articulating macro and micro levels?

In the late eighties and early nineties, when DNA profiling technologies began to be used as auxiliary tools in criminal identification, there were not any protocols nor rules regarding the interpretation of the information obtained from genetic profiles. Likewise, there was not a consensus in the scientific community about how to perform DNA analyses and interpret the results (Aronson, 2008; Derksen, 2010; Lynch, 1998). Nowadays, things are different: there are protocols, quality patterns for laboratories and legal frameworks. That is to say, a broad and stable network of social structures was created to frame and sustain the production and dissemination of knowledge about forensic genetics and its generalized acceptance in the criminal justice system (Hindmarsh \& Prainsack, 2010; Lynch et al., 2008; Williams \& Johnson, 2008). The scientific knowledge that led to the discovery of DNA technologies was, therefore, expanded from its local production context and integrated into the social order of various institutions, consequently stepping up from the microinteraction level to the social structure's macro level (Daemmrich, 1998; Derksen, 2003). In other words, we could say that the consensus around 
DNA technologies represents the outcomes of successful knowledgemaking activities (Derksen, 2010; Knorr-Cetina, 1999; Shapin, 1986).

When analysing the relationships between the micro and macro levels of social reality, we will consider the research undertaken by the sociologist Linda Derksen, who studied the development of DNA profiling technologies and their application in the justice system of the US (Derksen, $2000,2003,2010)$. The author resorted to two theoretical sociology guiding lines: sociology of scientific knowledge (SSK) and the sociological theories which articulate macro and micro levels. Her approach uses examples from the history of DNA profiling to show specific, particular moments where the micro (for instance, consensus between two people about the validity of a DNA profile interpretation method) and macro (e.g., creating legislation for databases with thousands of genetic profiles) levels were translated into one another. Therefore, the author studied examples from the history of DNA profiling which show specific moments of translation where new knowledge is produced at micro level and is then taken up-entrenched-into new social structures at macro level (see also Aronson, 2008). In concrete terms, Linda Derksen argues that the stabilization and standardization process of scientific knowledge generated around DNA profiling technologies led to the creation of new and diverse social structures. These social structures are what Anthony Giddens defines as rules and regulations and institutionalized patterns of behaviour (Giddens, 1984).

By applying the notion of social structure to DNA profiling technologies, we may refer to the stabilization of practices and protocols, the formation of expert communities and their professional associations, the creation of standards for laboratory practices and quality monitoring, as well as to the construction of databases, political projects and legislation. It should be noted that one social structure encapsulates formal and informal dimensions of social relations, knowledge and tacit rules, as well as legislation and regulations, without forgetting material resources and advisory and governing bodies. At a more macro level, we can even mention a type of society and culture that has made it possible to develop and expand DNA profiling databases and put them in the service of a criminal justice system: in this case, we are discussing a capitalist society and a Western culture.

For example, a concrete example of the creation of new and diverse social structures in forensic genetics is linked to the case of England and Wales, who created, in 1995, the first forensic DNA database: the National 
DNA Database (NDNAD). Because of its significant expansion, from an early stage, NDNAD began to deal with the societal effects triggered by various ethical controversies concerning the massive social implications linked to its size and scope (Human Genetics Commission, 2009; Nuffield Council on Bioethics, 2007; Skinner, 2013). These experiences have stimulated the development of stricter regulation to protect citizens' rights and, by extension, have also motivated the creation of particular social structures. Nowadays, the system of oversight of the NDNAD is formed by a partnership of boards and appointed experts, including (but not restricted to): the National DNA Database Strategy Board that provides governance and oversight over the operation of the National DNA Database and the National Fingerprint Database; The UK National DNA Database Ethics Group that provides independent advice on ethical issues; The Biometrics Commissioner whose role is to keep under review the retention and use by the police of DNA samples, DNA profiles and fingerprints; and The Forensic Science Regulator that ensures that the provision of forensic science services across the criminal justice system is subject to appropriate scientific quality standards.

\section{Continuum Between Subjective and Objective}

Another level of sociological analysis is linked to the relationship between "subjective" and "objective". While the subjective field is in the sphere of ideas, the objective one refers to real, material events (Ritzer, 1992, p. 643). Every society has an objective dimension-for example, laws and bureaucracy_and a subjective dimension-norms and values.

The continuum between subjective and objective is important to understand another crucial element of DNA technologies: the analysis of a genetic sample and the interpretation of the genetic profile extracted from that sample involve an act of translation and materialization into quantifiable values. The act of deciding if a specific genetic profile matches another genetic profile involves an assessment and also entails communicating and revealing publicly to other laboratories a quantity called the standard error of measurement. The existence of protocols for the interpretation of genetic analyses and the quantification of the standard error of measurement turn subjective assessments and evaluative statements invisible, thereby producing a kind of knowledge considered as "objective" (Derksen, 2000). As the science historian Theodor Porter indicates, quantification is one of the most important tasks in scientific 
practice because it transforms a knowledge claim from one which originates in a specific place and time to one which seems as if it could come from anywhere (Porter, 1995).

Quantification makes it possible to translate results into numbers, "erasing" the makes of human work (subjective) from the creation of scientific knowledge (which is supposed to be objective). In Western cultures, quantification is one of the most important processes to create what we call objective knowledge and "facts". In the words of Linda Derksen, "successful quantification hides the representing subject, it hides subjective judgments and it renders judgment invisible" (Derksen, 2010, p. 223). This creation process of "objective" knowledge through protocols, standards and turning certain classifications invisible (Bowker \& Star, 1999) made it possible for DNA profiling technologies to be seen as increasingly credible and reliable.

Laboratory studies, ${ }^{1}$ which were quite popular at the start of the $90 \mathrm{~s}$, showed, through ethnographic observation, how scientists generate among themselves interactive processes that make it possible to reach a consensus, in order to agree upon what a good match is or is not. In other words, accurate measurements are contingent, local achievements (Derksen, 2000; Kruse, 2016; Lynch et al., 2008). Some authors have noted the existence of cooperation activities, aiming to reach consensus, so a standard can be expanded and used by heterogeneous communities, as well as used in different activities and places (Bowker \& Star, 1999)—an approach that is close to the functionalist perspective.

On the contrary, other authors have emphasized activities of differentiation and conflict, which leads to specific professional groups being able to impose their interests while driving away those of others. One example of this approach, as connected to the abovementioned conflicts theories, is the study undertaken by Jay Aronson on the role of the FBI in standardizing the techniques for forensic DNA profiling. According to the author, this standardization was the result of FBI practices with the goal of becoming the dominant agents in the market of supply of forensic genetics analysis services. To be successful, the FBI agents created a technological

\footnotetext{
${ }^{1}$ Laboratory studies represent the study of science and technology through direct observation and discourse analysis at the root where knowledge is produced and constituted as such. This approach is very emblematic of the way the micro and macro dimensions intersect. On the one hand, laboratory social studies are focused on practices and interactions in a specific location (the scientific laboratory), while on the other hand, they highlight the construction and consolidation of power relations in modern societies (Knorr-Cetina, 1995).
} 
infrastructure and a laboratory network that imposed their approach to the activities already being developed by private companies. At the same time, the FBI recruited prestigious forensic scientists to validate and lend credibility to the products and methods being developed by them (Aronson, 2008). This kind of approach allows us to understand how the stabilization of networks and structures for some actors may lead to the exclusion of others-a kind of perspective that emphasizes power inequalities within forensic genetics (Quinlan, 2014).

After "stabilizing" the credibility of DNA profiling technologies, it was possible to store the DNA profiles in vast computer databases and disseminate them among the different social actors in the justice system, locally, nationally and internationally. Nowadays, DNA profiles can be shared and compared between different laboratories, provided that they use the same computer system and have adopted the same protocols (Aronson, 2007, 2008; Machado \& Granja, 2018; Santos, 2017).

The possibility of DNA profiles being "portable" was made attainable due to the creation of protocols and standards. Subsequently, this led to the expansion and consolidation of the use of forensic genetics in the criminal justice system, including a reinforcement of the cooperation mechanisms between police forces of different countries-a theme which will be addressed on Chap. 7 of this book. When knowledge is transformed into a quantitative format, it is easier for that knowledge to "travel" outside the place where it was produced and being appropriated or used by other social actors (Machado \& Granja, 2018)-in other words, through quantification, forensic geneticists can assume that the knowledge produced in a specific location follows "universal" guidelines that can be replicated by different people in different locations and reach the same results, thereby obtaining a kind of "local universality" (Timmermans \& Berg, 1997).

\section{Consolidation of the Social Studies in Forensic Genetics}

The continuum between subjective and objective is very complex and intersects with macro and micro levels of social reality. The various works undertaken within the social studies of forensic genetics, consolidating it as an autonomous field of study, have shown exactly that relationship, which is also perceived and captured through different methodological strategies. In this last section, we will do a brief review of the empirical studies connected to the use of forensic genetics in the criminal justice system. 
Focusing on the specific case of England and Wales, Robin Williams and Paul Johnson (Williams \& Johnson, 2004, 2008) explored the operational, legal and political aspects that have been brought to the fore while establishing and expanding the use of DNA technologies and the NDNAD. Taking into consideration the way different knowledges, practices and routines jointly constituted the NDNAD, the authors have analysed the perspectives of different specialist areas. Coupled with documentary analysis, they conducted 60 semi-structured interviews featuring a range of individuals from organizations directly involved in either making use of or commenting upon the use of DNA profiling in the criminal justice system-the police, forensic scientists, crime scene examiners, legal professionals, legislators and those concerned with human rights issues.

The analysis undertaken by the authors shows how different representations of the potential and actual application of DNA are employed to support alternative ethical assertions about the forensic uses of DNA technologies and DNA databases. The authors differentiate three representations about the perceived "essence" of DNA and its applications in terms of criminal investigation. Firstly, "genetic exceptionalism" which stresses the unique character of genetic material, a perspective generally supported by members of ethics committees and human rights groups. Secondly, "genomic minimalism" which emphasizes the mundane character of forensic uses of non-coding sequences of DNA, more frequently adopted by civil servants working in the criminal justice system. Lastly, "biometric pragmatism" which distinguishes between different sources of DNA material and what may legitimately be done with DNA obtained from these sources. This position is usually mobilized by criminal investigators and prosecutors and by some academic forensic experts (Williams \& Johnson, 2004 , p. 211). Based on their extensive work, the authors, therefore, articulated the perceptions, intentions and interpretations conferred by social actors to DNA to the broader social structures and contexts, namely their professional occupation and respective epistemic cultures (KnorrCetina, 1999).

Another example of the articulation between the macro and micro levels is the study by the sociologist Christopher Lawless (2011). In the aftermath of the closure of the Forensic Science Service (FSS), the leading provider of scientific support to police investigations in the UK, Lawless explored the impact of neoliberal policies in the evolution of the relationship between science and the criminal justice system. The study was based 
on documentary analysis, semi-structured interviews and a focus group with professionals from a commercial forensic science provider. Based on a micro-level analysis, Lawless explored the ways through which neoliberalism-by privatizing services — reformulated the epistemic possibilities for scientists and police professionals. He also showed how that reformulation coexisted with situated practices of resistance to attempts of moulding science into commercial types of knowledge in service of law enforcement. Therefore, Lawless work shows how large-scale phenomena, like the capitalist system and neoliberal policies, directly intertwine with interactions on a micro scale.

Continuing to dwell on the studies that have sought to understand the different perspectives by professionals working on forensic genetics, some authors have also used ethnography to capture and analyse the way some professionals act and assign meaning to their practices. In this regard, we highlight the work of the anthropologist Corinna Kruse, who accompanied the daily procedures of the Swedish National Laboratory of Forensic Science, observing day-to-day operations of a public prosecutor office, a criminal investigation division and a crime scene division, as well as observing trials. This way, Kruse was able to analyse the various instances that constitute DNA's chain of custody. Based upon a research performed on a micro level, that paid attention to the practices and perceptions of social actors, the author showed how the social life of forensic evidence takes into account how knowledge is produced by and transported across a cooperation of an array of epistemic cultures (Kruse, 2016, p. 148).

Generally speaking, the studies referred so far highlight how researchers have "followed", according to the Actor-Network Theory (Latour, 2005 ) traditions, how social actors with various levels of authority, credibility and power act and leave visible traces of their actions, such as protocols, reports, forensic samples and forensic technologies. However, there are other marginal actors, "the one who both belongs and does not belong" (Quinlan, 2014) which also take part in the use of forensic genetics in the governance of crime. One example of these actors are, for instance, the prisoners whose biological samples are collected. On this level, we should refer to the comparative study between Austria and Portugal developed by Helena Machado and Barbara Prainsack. Based on interviews with prisoners, the authors sought to understand the point of view of this group about criminal investigation practices based on DNA technologies. This study brought to light the ambivalent perspectives that prisoners have in relation to DNA technologies. On the one hand, they 
find it an important tool to identify and convict offenders or to acquit and exonerate suspects. On the other hand, they show doubts and uncertainty about the potential abuses they may fall victim to, and about the supposed deterrent effect of DNA technologies in crime prevention (Machado \& Prainsack, 2012).

Continuing in the field of public perception, other authors have also expanded the literature on the social studies of forensic genetics, by conducting studies focused on public perceptions about DNA databases, whether through qualitative methodologies (Anderson, Stackhouse, Shaw, \& Iredale, 2010; Machado \& Prainsack, 2012; Stackhouse, Anderson, Shaw, \& Iredale, 2010; Wilson-Kovacs, Wyatt, \& Hauskeller, 2012) or quantitative ones (an extensive review of the existing studies can be found at Machado \& Silva, 2019). In this regard, we underscore the work of the sociologist Dana Wilson-Kovacs and colleagues (Wilson-Kovacs et al., 2012). By analysing the results of "The Mass Observation Project" which, since 1981, has collected and analysed detailed answers to questions about specific themes in order to gather information about the lives of normal people, this study shows how DNA profiling is seen by the participants as one of the less problematic applications of genetics.

As a whole, these studies reveal how social representations that the social actors may harbour towards forensic genetics (subjective dimension) may vary according to objective dimensions, namely the socio-economic condition, profession, gender, race or ethnicity. For example, the study by Machado and Prainsack (2012) notes how prisoners consider that having their genetic profile on a forensic DNA database managed by the police may reinforce the stigmatization towards individuals who have committed crimes (Machado \& Prainsack, 2012). Other studies have also revealed that individuals from disadvantaged social groups and racial and ethnic minorities present a high degree of mistrust about the use of genetic evidence in the criminal justice system (Curtis, 2009; Duster, 2006; Machado \& Silva, 2019).

\section{CONCluding Remarks}

A sociological approach to the use of forensic genetics in the governance of crime makes it necessary to consider the multiple social actors who interact among themselves, as well as the organizational context where they develop their activities. Developing a sociological study about forensic genetics in the criminal justice system also entails considering macro 
and micro, objective and subjective dimensions that frame and provide context to the interactions and representations of individuals and groups.

Let us begin by considering in detail the multiple social actors involved in the social processes linked to the use of forensic genetics in the criminal justice system. In terms of forensic genetics, we have a significantly heterogeneous community: from the laboratory technicians who receive the biological samples collected at the crime scene and dedicate themselves to analysing the materials to scientists who undertake research in the field of genetics, focusing their actions on innovations within the scope of genetic analysis techniques, without dealing directly with real cases. There are also those scientists who are directly involved with criminal cases, while not necessarily developing research in the field of forensic genetics: they generally have roles such as directors of forensic genetics laboratories, being responsible for the scientific validity of the analysis methods applied (Cole, 2013). Lastly, in several countries, the criminal investigation police forces integrate groups of forensic experts - or police officers with specific training-who visit the crime scenes to select and collect the traces which will subsequently be forwarded for laboratory analysis (Costa, 2017; Kruse, 2016; Santos, 2014). In terms of the criminal justice system, there is an even greater differentiation and diversity of social actors involved, who have diversified types of expert knowledge and professional cultures. They act in different areas: from police forces to court professionals, and the latter group includes judges, prosecutors, attorneys and juries.

The use of forensic genetics in the governance of crime also involves other social actors, whose scope of action has diverse social, political and cultural implications: for instance, the companies which supply equipment, instruments and other materials to laboratories, without forgetting that some of them provide forensic genetics analysis for courts of law (Lawless, 2011; Wienroth, 2018). Another type of social actors are the groups who deal with ethical and legal issues linked to the use of forensic genetics for criminal identification, namely through their role as entities who supervise and monitor the activities of databases which contain thousands of genetic profiles of citizens (Nuffield Council on Bioethics, 2007). Finally, there are also professional organizations in the field of forensic genetics, whose actions have international implications in terms of standardization and harmonization of procedures (e.g., in laboratories, law-enforcement or judicially): the politicians who decide the legal and regulatory framework which governs the application of genetic information in criminal identification; the non-governmental organizations who 
function as critical, vigilant voices regarding the risks of curtailing human rights as a result of the massive expansion of forensic DNA databases; people whose genetic profile is included in such databases (Machado \& Prainsack, 2012), as well as other citizens (Anderson et al., 2010; Stackhouse et al., 2010; Wilson-Kovacs et al., 2012).

Lastly, there is another group that is also part of this diverse set of social actors involved in the social processes linked to the application of forensic genetics in the criminal justice system, a group which is often disregarded by social studies of forensic genetics: the survivors and victims of crime. According to Andrea Quinlan (2014), this group of social actors, who she names marginal actors, "sits simultaneously inside and outside of the legal system's institutional network [...] 'inside' in the sense that their body serves as the" crime scene "from which DNA evidence is gathered [...] 'outside' as they are excluded from many of the practices within the legal system" (Quinlan, 2014). Paying attention to this set of actors would make it possible to create a "network from below" following the tradition of the Actor-Network Theory (Latour, 2005).

The heterogeneous nature of the social actors who are potentially involved in the social phenomenon of application of genetic technologies to the criminal justice system corresponds to different kinds of actions, knowledge, experiences and perspectives on society. Therefore, various sociologically pertinent issues may serve as the basis for studies in the field. The different chapters of this book have the goal of showing the various themes and issues that can be studied through a sociological point of view.

\section{REFERENCES}

Anderson, C., Stackhouse, R., Shaw, A., \& Iredale, R. (2010). The national DNA database on trial: Engaging young people in South Wales with genetics. Public Understanding of Science, 20(2), 146-162. https://doi.org/10.1177/ 0963662510375793

Aronson, J. (2007). Genetic witness: Science, law, and controversy in the making of DNA profiling. Piscataway, NJ: Rutgers University Press.

Aronson, J. (2008). Creating the network and the actors: The FBI's role in the standardization of forensic DNA profiling. BioSocieties, 3(2), 195-215. https:// doi.org/10.1017/S174585520800611X

Bourdieu, P. (1977). Outline a theory of practice. Cambridge: Cambridge University Press. 
Bowker, G., \& Star, S. L. (1999). Sorting things out: Classification and its consequences. Cambridge, MA and London: The MIT Press. https://doi. org/10.1109/MAHC.2000.841148

Cole, S. (2013). Forensic culture as epistemic culture: The sociology of forensic science. Studies in History and Philosophy of Biological and Biomedical Sciences, 44(1), 36-46. https://doi.org/10.1016/j.shpsc.2012.09.003

Costa, S. (2017). Visibilities, invisibilities and twilight zones at the crime scene in Portugal. New Genetics and Society, 36(4), 375-399. https://doi.org/10.108 0/14636778.2017.1394835

Curtis, C. (2009). Public perceptions and expectations of the forensic use of DNA: Results of a preliminary study. Bulletin of Science, Technology \& Society, 29(4), 313-324. https://doi.org/10.1177/0270467609336306

Daemmrich, A. (1998). The evidence does not speak for itself: Expert witnesses and the organization of DNA-typing companies. Social Studies of Science, 28(56), 741-772.

Derksen, L. (2000). Towards a sociology of measurement. Social Studies of Science, 30(6), 803-845. https://doi.org/10.1177/030631200030006001

Derksen, L. (2003). Agency and structure in the history of DNA profiling: The stabilization and standardization of a new technology. San Diego: University of California. Retrieved from https://www.academia.edu/1407355/Agency_ and_structure_in_the_history_of_DNA_profiling_The_stabilization_and_standardization_of_a_new_technology

Derksen, L. (2010). Micro/macro translations: The production of new social structures in the case of DNA profiling. Sociological Inquiry, 80(2), 214-240. https://doi.org/10.1111/j.1475-682X.2010.00328.x

Durkheim, É. (1895). The rules of sociological method. New York: Free Press.

Durkheim, É. (1897). Suicide. New York: Free Press.

Duster, T. (2006). Explaining differential trust of DNA forensic technology: Grounded assessment or inexplicable paranoia? Journal of Law, Medicine is Ethics, 34(2), 293-300.

Giddens, A. (1979). Central problems in social theory: Action, structure and contradiction in social analysis. Berkeley and Los Angeles: University of California Press.

Giddens, A. (1984). The constitution of society. Berkeley and Los Angeles: University of California Press.

Hard, M. (1993). Beyond harmony and consensus: A social conflict approach to technology. Science Technology Human Values, 18(4), 408-432. https://doi. org/10.1177/016224399301800402

Hindmarsh, R., \& Prainsack, B. (Eds.). (2010). Genetic suspects: Global governance of forensic DNA profiling and databasing. Cambridge: Cambridge University Press.

Human Genetics Commission. (2009). Nothing to hide, nothing to fear? Balancing individual rights and the public interest in the governance and use of the National 
DNA Database https://www.statewatch.org/news/2009/nov/uk-dnahuman-genetics-commission.pdf.

Jasanoff, S. (1995). Science at the bar. Law, science, and technology in America. Cambridge, MA and London, UK: Harvard University Press.

Knorr-Cetina, K. (1995). Laboratory studies: The cultural approach to the study of science. In Handbook of science and technology studies (pp. 140-166). London: Sage Publications.

Knorr-Cetina, K. (1999). Epistemic cultures: How the sciences make knowledge. Cambridge, MA: Harvard University Press.

Kruse, C. (2016). The social life of forensic evidence. Oakland, CA: University of California Press.

Latour, B. (2005). Reassembling the social. An introduction to actor-network-theory. Oxford: Oxford University Press.

Lawless, C. (2011). Policing markets: The contested shaping of neo-liberal forensic science. British Journal of Criminology, 51(4), 671-689. https://doi. org/10.1093/bjc/azr025

Lynch, M. (1993). Scientific practice and ordinary action: Ethnomethodology and social studies of science. New York: Cambridge University Press.

Lynch, M. (1998). The discursive production of uncertainty: The OJ Simpson 'Dream Team' and the sociology of knowledge machine. Social Studies of Science, 28(5-6), 829-868.

Lynch, M. (2013). Science, truth, and forensic cultures: The exceptional legal status of DNA evidence. Studies in History and Philosophy of Biological and Biomedical Sciences, 44(1), 60-70. https://doi.org/10.1016/j.shpsc.2012. 09.008

Lynch, M., Cole, S., McNally, R., \& Jordan, K. (2008). Truth machine: The contentious history of DNA fingerprinting. Chicago: University of Chicago Press.

Lynch, M., \& Jasanoff, S. (1998). Contested identities: Science, law and forensic practice. Social Studies of Science, 28(5-6), 675-686. https://doi. org/10.1177/030631298028005001

Machado, H., \& Granja, R. (2018). Ethics in transnational forensic DNA data exchange in the EU: Constructing boundaries and managing controversies. Science as Culture, 27(2), 242-264. https://doi.org/10.1080/09505431. 2018.1425385

Machado, H., \& Prainsack, B. (2012). Tracing technologies: Prisoners' views in the era of CSI. Farnham, UK: Ashgate.

Machado, H., \& Silva, S. (2019). What influences public views on forensic DNA testing in the criminal field? A scoping review of quantitative evidence. Human Genomics, 13(1), 23. https://doi.org/10.1186/s40246-019-0207-5

Nuffield Council on Bioethics. (2007). The forensic use of bioinformation: Ethical issues. London.

Porter, T. M. (1995). Trust in numbers: The pursuit of objectivity in science and public life. Princeton, NJ: Princeton University Press. 
Quinlan, A. (2014). Studying DNA: Envisioning new intersections between feminist methodologies and actor-network theory. In A. Tatnall (Ed.), Technological advancements and the impact of actor-network theory (pp. 196-208). Hershey, PA: IGI-Global. https://doi.org/10.4018/978-1-4666-6126-4.ch011

Ritzer, G. (1992). Sociological theory. Singapore: Mc-Graw Hill International Editions.

Santos, F. (2014). Making sense of the story: The dialogues between the police and forensic laboratories in the construction of DNA evidence. New Genetics and Society, 33(2), 181-203. https://doi.org/10.1080/14636778.2014. 916186

Santos, F. (2017). The transnational exchange of DNA data: Global standards and local practices. In K. Jakobs \& K. Blind (Eds.), Proceedings of the $22 n d$ EURAS annual standardisation conference. Digitalisation: Challenge and opportunity for standardisation (pp. 305-322). Aachen: Verlag Mainz.

Shapin, S. (1986). The Social history of truth. Chicago: Chicago University Press.

Skinner, D. (2013). "The NDNAD has no ability in itself to be discriminatory": Ethnicity and the governance of the UK National DNA Database. Sociology, 47(5), 976-992. https://doi.org/10.1177/0038038513493539

Stackhouse, R., Anderson, C., Shaw, A., \& Iredale, R. (2010). Avoiding the "usual suspects": Young people's views of the National DNA Database. New Genetics and Society, 29(2), 149-166. https://doi.org/10.1080/14636778.2010. 484234

Timmermans, S., \& Berg, M. (1997). Standardization in action: Achieving local universality through medical protocols. Social Studies of Science, 27(2), 273305. https://doi.org/10.1177/030631297027002003

Weber, M. (1949). The methodology of social sciences. New York: Free Press.

Wienroth, M. (2018). Socio-technical disagreements as ethical fora: Parabon NanoLab's forensic DNA Snapshot ${ }^{\mathrm{TM}}$ service at the intersection of discourses around robust science, technology validation, and commerce. BioSocieties, 1-18. https://doi.org/10.1057/s41292-018-0138-8

Williams, R., \& Johnson, P. (2004). "Wonderment and dread": Representations of DNA in ethical disputes about forensic DNA databases. New Genetics and Society, 23(2), 205-223. https://doi.org/10.1080/1463677042000237035

Williams, R., \& Johnson, P. (2008). Genetic policing: The use of DNA in criminal investigations. Cullompton: Willan Publishing.

Wilson-Kovacs, D., Wyatt, D., \& Hauskeller, C. (2012). “A Faustian bargain?” Public voices on forensic DNA technologies and the National DNA Database. New Genetics and Society, 31(3), 285-298. Retrieved from http://www.tandfonline.com/doi/abs/10.1080/14636778.2012.687085 
Open Access This chapter is licensed under the terms of the Creative Commons Attribution 4.0 International License (http://creativecommons.org/licenses/ by $/ 4.0 /$ ), which permits use, sharing, adaptation, distribution and reproduction in any medium or format, as long as you give appropriate credit to the original author(s) and the source, provide a link to the Creative Commons licence and indicate if changes were made.

The images or other third party material in this chapter are included in the chapter's Creative Commons licence, unless indicated otherwise in a credit line to the material. If material is not included in the chapter's Creative Commons licence and your intended use is not permitted by statutory regulation or exceeds the permitted use, you will need to obtain permission directly from the copyright holder.

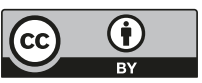

